Corresponding Author: Mohd Daud Awang amdaud@upm.edu.my

Received: 2 May 2020 Accepted: 4 July 2020 Published: 14 July 2020

Publishing services provided by Knowledge E

(c) Nur Bahirah Baharum et al. This article is distributed under the terms of the Creative Commons Attribution License, which permits unrestricted use and redistribution provided that the original author and source are credited.

Selection and Peer-review under the responsibility of the ICIEHI Conference Committee.

\section{A Study of Literatures: Status of Alcohol in Cosmetics Products from Shariah Views in Malaysia}

\author{
Nur Bahirah Baharum¹, Mohd Daud Awang ${ }^{1,2}$, Syariena Arshad ${ }^{1}$, and Siti Salwa \\ Abd Gani1,3 \\ ${ }^{1}$ Halal Products Research Institute, Universiti Putra Malaysia \\ ${ }^{2}$ Department of Government and Civilization Studies, Faculty of Human Ecology, Universiti Putra \\ Malaysia \\ ${ }^{3}$ Department of Agriculture Technology, Faculty of Agriculture, Universiti Putra Malaysia
}

\section{Abstract}

Alcohol is an organic solvent that is widely used in the manufacturing industry, especially in food and beverage products. It is also widely used in cosmetic industries to produce products such as perfume, moisturizer and other personal care products. Despite its widespread application, discussions regarding the use of alcohol in cosmetics from the Shariah and scientific perspectives are still very limited. Thus, the main focus of the present study is to consider the halal status of alcohol as an ingredient in Shariah-based cosmetic products in Malaysia. The analysis focuses on different aspects of Shariah law and also draws on scientific findings from previous studies. Opinion from scholars in Shariah and scientific field are examined in this articles, and the different types of alcohol found in cosmetic products are also discussed.

Keywords: alcohol, cosmetic products, Shariah

\section{Introduction}

Islam does not forbid a men or women who wants to be beautiful. But it does not have to be excessive, just as necessary. Beauty is a subjective matter for every woman. Undoubtedly, now many women in the modern era of the globalization are more concerned with the beauty of appearance than the beauty of the soul. They are willing to pursue and spend a lot of money for cosmetics to get a bright skin and beautiful looks. Cosmetics also is a symbol of beauty for a woman. It is also a reflection of personality traits and self-confidence when going through daily life. Most women prefer to use cosmetic products that can make them look beautiful.

Nowadays, alcohol is usually used in some cosmetic products that have become a daily routine in people's lives. Alcohol is used as an ingredient in daily care products such as perfumes and skin care products that trendy people wears and used. In 
addition, alcohol term is always mistakenly understand as khamr, which is a beverage introduced from the time of Prophet Muhammad SAW. Based on (Daud, 2016) khamr is the intoxicating substance of alcohol. Not all alcohol is prohibited or not permissible (haram) in Islam, there are also alcohols that are permissible to be used.

Accordingly, alcohol is also called ethanol or ethyl alcohol which is found in various products such as cosmetics. According to Mahaiyadin \& Osman (2017), alcohol is a type of chemical that has many uses. Alcohol such as methanol is derived from wood and ethanol is derived from cereal. The alcohol commonly used in daily life is ethanol which is volatile, flammable, colorless, and has a distinctive aroma (Mulaina, 2014). The status of alcohol found in cosmetics need to be determined profoundly and accurately by Islam scholars and scientists.

Therefore, this article presents a review on the status of alcohol in Shariah and scientific point of view as well as to find the types of alcohol used in cosmetics products. In addition, this article also discusses the law of alcohol in cosmetics product according to Shariah.

\section{Methodology}

Data and discussion from academic materials which is consist of various source of journal, articles, website and another reading material such as book related to the study were used in this review. Therefore, data collected in the study is consist of secondary data.

\section{The Status of Alcohol in Islamic and Science}

\subsection{Alcohol in Islam}

Alcohol is the common name that has always been a conversation between current and earlier scholars. The use of alcohol is not only found in certain food and beverage product, but also most widely used in cosmetics such as perfume, skin care products, and other. If the use of alcohol in foods and beverages describe as not permissible, there are some disputes over the use of alcohol in cosmetics products. Islam is expected to influence the use alcohol for Muslim college students because of various ways of transforming through the sources of the Al-Quran and Sunnah sources specifically prohibit the use, transportation, and sale of alcohol (Abu-ras, Ahmed, \& Arfken, 2010). 
Initially, alcohol is among the substances found in the wine (khamr). Alcohol (khamr) is an alcoholic beverage that is haram in Islam. In Surah Al-Maidah verse 90, testifies that Allah Almighty forbids Muslim to drink (khamr) because it is an abominable act and includes the act of the devil. Therefore, alcohol (khamr) becomes il'lah because of the haram commandment on Muslim to drink it. So the Prophet Muhammad SAW has reaffirmed in his hadith which says "Every intoxicant is khamr and every khamr is haram".

As stated by Azahari (2010), the issue of alcohol solving is widespread in Malaysia. Therefore, Department of Islamic Development Malaysia (JAKIM), has specified that alcohol in perfumes, cosmetics, medicines and beverages is permissible (harus) and is acceptable if the alcohol content is not inferior. In addition, according to views of (Usmani, 2017), the meaning of alcohol in Shariah is not specifically specified, except the wine restriction(wine) made of grapes, date palm and other materials.

In addition, according to the book (Limited), in Al-Quran there is mention of khamr namely alcoholic drinks. During the reign of Prophet Muhammad SAW, these alcoholic beverages derived from grapes, dates palm, wheat, barley and honey. Although, alcohol is from the source of the other, it is still regarded as prohibited because of the intoxicating effects for Muslim. As well as some opinion from the western pastor that states alcohol is permissible to be used in cosmetics (Michalak \& Katz, 2010). They explained that Fatwa and Mufti describes alcohol in cosmetics are not prohibited as it is for external used only and not the purpose of drinking.

Afifi et al. (2014) discusses that alcohol is a colorless liquid produced by two ways of processing. Firstly, it can be produced by fermentation, the main process to produce liquor and secondly by chemical substances, which is a process to produce alcohol from petroleum. The product produced by this process is known as ethanol or ethyl alcohol. But, all the earlier scholars of Mazhab Hanafi, Mazhab Maliki, Mazhab Shafie and Mazhab Hambali agreed that alcohol is a najs because it can intoxicate. Thus, according to the views of Hashim, et. al (2009), they explained that to decide the halal status of cosmetic, the product must not contain any products or by-products from alcoholic beverages (khamr). (Abdul, 2014) states that the difference between alcohol and khamr is anything that can cause intoxicant from juice and Ibn Saiyidah said that khamr is from grape and other substance which caused intoxicant. While, Imam Hanafi states that khamr is intoxicant from grape juice only. The term alcohol from the chemistry perspective is more than just ethanol. Besides that, ethanol is not necessarily khamr although the intoxicating substance in khamr is ethanol. 
According to (Dr Erwandi Tarmizi, 2013) there are three different opinion from ulama regarding the legal ruling of alcohol and khamr. First opinion from most ulama today and the fatwa from the Council of Ulama of the Kingdom of Saudi Arabia says that alcohol is khamr, which explain anything that is consumed and can cause drunkenness is categorized as khamr, regardless of whether it is in a small or a large amount, and whether it is called alcohol or any other name. Second opinion is from Sheikh Muhammad Rasyid Ridha and several other modern ulama says alcohol is not khamr because khamr is the result of the fermentation of fresh fruits like grapes, dates, wheat and cereals, while alcohol can be made from wood, roots, fibers of sugarcane, orange, lemon and other. But, Prophet Muhammad SAW said in Hadith 'everything that is intoxicating is khamr and everything that is intoxicating is prohibited'. Thus, according to this hadith, alcohol also considered as khamr according to Islamic law and is treated according to the same rules as khamr, since alcohol is the main intoxicating component of many other drinks that are already considered as khamr.

(Izhar et al., 2017) states alcohol is originally impure and haram but it can turn into a clean and pure substance thorough the process of istihalah whereby the original nature of the alcohol substance turns into properties of common vinegar. For that reason, the determination of the law is taken into account through an examination of the final or end product. If the rule of law warrants that the end or final product is clean, pure and good, it is considered halal. If the rule of law affirm that end or final product is unclean and impure, it is haram for use. In addition, according to the study, (Panggabean, 2013) explains that khamr is classified as najs and not najs. There are two different views from Jumhur ulama, first it states that khamr is najs because commandment from Allah S.W.T in Surah Al-Maidah (50) explained that the meaning of word 'rijs' in verse is najs. Thus, they argue that the wine is defile as najs hissiyah (najs can perceive by the senses). Second view according to Rabi'ah, al-laits, al-Muzani and other from among the Salaf states that khamr is clean (not najs) because they concluded that najs remains whether khamr is the result of scholarly and not direct revelation from Allah and Rasulullah SAW whose law is qat'l (certain).

In general, khamr is a term refers to any substance that intoxicates the mind and can cause the person who took it lose their ability to control their mind and action. Mazhab Maliki, Shafie, Hanbali consider khamr to be any intoxicating drink made from grapes, dates, or raisins. According to Hadith Bukhari and Muslim, khamr is what covers intellect and made from five things which are grapes, dates, wheat, barley and honey. The prohibition of khamr is clearly stated in Al-Quran. Surah Al-Baqarah verse 219; 'they ask thee concerning wine and gambling, say: in them is great sin, and some profit, for 
men; but the sin greater than the profit'. (Ramli, 2018). On the other hand, (Community, 2012) explain that according to Malaysian Fatwa Committee of the National Council for Islamic Affairs, the use of alcohol in any food products which is not from alcoholic beverages (arak) source would be considered and declared halal by the authorities if the alcohol content did not exceed $0.01 \%$.

In addition, khamr (wine or alcohol) is not the only substance that is prohibited, but also extends to any substance that intoxicates, in whatever from or under whatever name it may appear are forbidden (haram). However, there are no prohibitions on using alcohol for scientific, medical, industrial or automotive use (as a biofuel, solvent or a coolant, for instance). (Rassool, 2014). In Islam, since 1400 years ago, khamr (wine) has been regarded as haram (prohibited). It has been an established principle of Islamic Law that the purpose for the prohibition of khamr is due to its intoxicating nature. Consuming alcohol is prohibited in Islam, but Islamic principle highlights that alcohol can be consumed if it go through natural fermentation called takhammur, takhallul and istihalah. (Ibrahim B. Syed, 2018).

Furthermore, there are several articles which summarize the benefits of alcohol to health as in Al-Quran about khamr and gambling which means, "In them there is a great $\sin$, and some of its benefits to humans, but their sin is greater than its benefits" (Surah Al-Baqarah verse 219). There are various types of alcohol and other ingredients used in perfumes and other facial cleansers. The topical use of alcohol is not prohibited in Islam, but foods and drinks containing alcohol are prohibited as mention in Al-Quran and Sunnah. Therefore, some of the scholars regard it as najs when exposed to human body or clothing and need to be cleaned immediately (Majid, Sabir, \& Ashraf, 2015).

There are many cosmetics contain alcohols as humectants that help deliver ingredients into skin, emollients, or cleansing agents. In addition, the cosmetics and pharmaceutical sector was subject to greater scrutiny by Muslim scholars on the suspicion that many international brands are using enzymes extracted from pork meat or alcohol as a preservative, generating great deal of cynicism towards these brands in Muslim customers.(Ahmad, Rahman, \& Rahman, 2015).

\subsection{Alcohol in Science}

Every command of Allah S.W.T have a specific reason through everything that is prohibited or beneficial to Muslims. Basically, alcohol is a hot issue in industrial products like food, beverages and especially in cosmetics. In this case, alcohol in cosmetics is often a topic of discussion among Malaysians. However, alcohol is a problem that many 
scientists have recently learned about in this field. Through study by (Jamaludin, Ramli, Hashim, \& Rahman, 2012) explained alcohol is obtained from fermentation of fruits or grains with the existence of yeast, sugar or starch. It is colorless, flammable and has been broadly accepted as one of the most popular beverages all over the world. It also used in other products in pure form or as a solvent in medicine, perfume, cleaning, bakery product and other.

According to (Mohammad Aizat Jamaludin, 2015), alcohol in a science perspective is a group of volatile, odorless chemical compounds that are not in the form of liquids or solids which can be naturally produced through the process of fermentation of agricultural materials such as grapes, wheat, seeds and honey. Next, in the journal by (Chandrahasam, 2013), argues that alcohol is an organic matter that contains carbon, hydrogen and oxygen elements. Alcohol is also a hydrocarbon compound that has covalently bonded hydroxyl.

Sawari et al. (2015) recognizes that alcohol is a scientifically refers to a group of chemicals with saturated hydroxyl derivatives in which hydroxyl group $(\mathrm{OH})$ is place on saturated carbon atoms. While view from Rahim (2016), alcohol is a chemical common in nature and has many uses and applications. Chemically, alcohol is refer to a class of organic compounds containing hydroxyl $(\mathrm{OH})$ groups. In addition, according to Jamaludin et. al., (2011), the process of alcohol preparation whether it is used internally or using denatured alcohol (non-dissolved) such as carbonated beverages or mixed ingredients in food. Meanwhile, for external use or denature alcohol (dehydrated) involves fragrances such as perfume, deodorant and spray.

According to Noor (2018), she describes alcohol from the scientific point of view, is an organic compound consisting of carbon $\mathrm{C}$, hydrogen $\mathrm{H}$, oxygen $\mathrm{O}$ which has a general formula $\mathrm{C}_{n} \mathrm{H}_{2 n+1} \mathrm{OH}$ for aliphatic alcohols and aromatic alcohols or known as phenol $\mathrm{C}_{6} \mathrm{H}_{5} \mathrm{OH}$. While (Suryatin, 2004) gives a view that alcohol is also called a cereal alcohol, a chemical compound that has a molecular formula of $\mathrm{C}_{2} \mathrm{H}_{5} \mathrm{OH}$ or ethanol. The physical properties of material are very vivid because it is colorless, often evaporating and soluble in water which results from the fermentation process.

In the journal article about the study of alcohol content in beverage products found in the market by (Ruskam), states that alcohol is a chemical compound that has a hydroxyl functional group $(-\mathrm{OH})$ such as methanol, ethanol, butanol and others which is as solvents, fire, starting material for the preparation of other organic compounds and in the industrial field. (Alkohol \& Disinfekta, n.d.) explained alcohol is the disinfection of highly effective bactericidal, broad spectrum and no chemical waste. Therefore, the concentration of alcohol is effective between 60-90\%. (Label \& Cashion, 1990) explain 
that one object of the present invention is to give a high alcohol content gel composition for frequent use which is antimicrobial owing to presence of the alcohol while at the same time provides a level of skin conditioning and moisturization to the skin which is more akin to a hand and body lotion.

Furthermore, (Newman, 1999) explain the benefits of alcohol is to offer an effective alcohol-containing antimicrobial composition in cosmetics that possesses the feel, moisturizer attributes of hand cream and lotion. It is also to give an appearance of moisturizing products to overcome the perceived drying of topical alcohol-containing formulation. These two aspects in any product or formulation would give multi-functions roles such as antibacterial efficacy, mildness, moisturization and protection. In addition (Duhigg, 2011) stated that in Egypt, they produced many essences used by French perfumes and sold it by the ounce to diluted, 1:9 in alcohol for perfume.

\section{Type of Alcohol}

There are various types of alcohol used in products such as ethanol, cetyl alcohol, isopropyl alcohol and others. The typical alcohol found in cosmetics is ethanol and according to (Cabaleiro, Calle, Bendicho, \& Lavilla, 2012) ethanol is added into cosmetics due to its antimicrobial action and its activity as tropical penetration enhancer. Besides that, ethanol is also used as a solvent, viscosity decreasing agent and antifoam agent. Therefore, it is not surprising that many cosmetics product contained traces of ethanol in the last formulation.

Syariena et. al,. (2014) explained ethanol is also widely used as a solvent in all types of products such as product personal care, pharmaceutical, direct exposure to human skin and includes perfume products. The perfumes contain main ingredients such as water and fragrances, with ethanol levels of $50 \%$ to $80 \%$. It also has advantage of rapid drying rate and gives a strong aroma after applying to the skin. In addition, according to (Spirit, 2001), the methyl alcohol is an aliphatic alcohol that serves as a solvent and a denature in a cosmetic products. Methyl alcohol also easily absorbed through the skin, digestive tract, and entire organs and tissues that continue to the water area irrespective of the route of exposure.

There is also the use of raw ethanol an ingredient (70\%-95\% ethanol content) for pharmaceutical, cosmetics and disinfectant purposes (Joseph, 2013). Accordingly, there are some studies regarding the usage of cetyl alcohol as a cosmetics ingredient. According to (Cirillo et. al., (2018), cetyl palmitic estate is one of the candles applied in the cosmetics industry due to its emollient characteristics. It is also used as a surfactant 
in shampoo, emulsifying agent, thick cream and adds texture to a variety of wood-based make-up products.

According to the journal by Hills \& Ag (2003), cetyl alcohol is used in the formation of cosmetics in addition to a viscosity of the crèmes with the unclear amount found in alcohol and esters. This product causes a problem in formulating skin care products. Furthermore, the new enzymatically manufactured product is specified with a defined low cetyl alcohol content, which will allow development of new types of formulations with this product as the rheology effects of cetyl alcohol in cosmetics emulsions can now be controlled.

Besides that, facial masks constituted of polyvinyl alcohol (PVA) produced occlusion and tensor action after drying, then, making the skin softer to touch. If an active substance is added to the formulation, the action will be increased (Vieira et al., 2009). Journal of 'On, Assessment, \& Polyvinyl (1989)' explained that polyvinyl alcohol is used in cosmetic formulations such as in facial masks, eye shadow products, lip liners and skin care products. Ethanol is used in perfume because it is a very good solvent, it helps to add each ingredient at the desired concentration and helps to achieve a transparent solution (Srinivasan, 2017).

However, it is well known that oil-in-water (O/W) creams and milky lotions used in cosmetics skincare products formulate from water, oils, surfactants and fatty alcohol. These products are used to improve the appearance and condition of the skin (Okamoto, Tomomasa, \& Nakajima, 2016). Liu et. al., (2014) explain that fatty alcohol are an important form of chemical raw material due to their amphipathic nature. Fatty alcohol also widely used in detergents, skin care products, cosmetics, medicines, and have the potential to be used as fuel.

According to (Liebert, 1968), long-chain aliphatic alcohols are widely used in skin lotions and creams, those most commonly used range are from 12 to 18 carbon in length. Besides that, cetyl alcohol used as an emollient to prevent drying and convulsion of the skin because of its water-binding property. The simple esters with lower chain alcohols such as methyl-, ethyl-, n propyl-, isopropyl- and butyl esters used as emollients in cosmetics, personal care products and lubricants (Bhatia, 2004).

From journal (Baranowska, Wojciechowska, Solarz, \& Krutysza, 2014) explaining that benzyl alcohol (BA) is also used as one of the fragrance ingredients in perfume products. However, benzyl alcohol can also penetrates the skin to a significant extent of 9 to 13 and is more often reported contact allergens, possibly because of its widespread use in both fragrance and preservative systems for cosmetic products (Saiyasombati \& Kasting, 2003). In addition, from book Chemistry and Technology of Flavors and Fragrances by 
(Rowe, 2005), to produce a perfume, the fragrance oil is added into a solution of alcohol and water. The commercial alcohol is not a single ingredient, but contain ethanol, water and denaturant.

Moreover, there are some compounds from this group serves as masking in reducing or inhibiting the basic odour or taste of the product, as ingredients flavor to the cosmetic product and denaturing, making cosmetics unpalatable, mostly added to cosmetics containing ethyl alcohol ingredients (A.Gunia Krzyzak, 2018). (Ishiwatari et al., 1991) describe that invention relates to a water and polyhydric alcohol-in-oil type emulsified composition is useful as a cosmetic or ointment base. Besides that, in journal Applications of microemulsions in cosmetics by (Boonme, 2007), found cetyl alcohol and octyl dimethyl para- aminobenzoix acid (PABA) formulated in w/o micro emulsions were able to permeate through the skin at higher amounts than those in creams and lotions. It can be applied for cosmetic products.

\section{The Law of Alcohol in Cosmetics Product According to Shariah}

It is said in medieval times that the most important chemical discovery is alcohol and mineral acids through the distillation process developed and controlled by the Arabs. Distillation was one of the most important processes in Islamic chemical technology and was employed for both medicinal preparations and a variety of other technological and industrial uses, including the preparation of acids, the distillation of perfume, rosewater and essential oils (Rachel Hajar, 2000).

According to (M. Hashim, 2013), the sources of ingredients of halal cosmetics products can include halal animals (land and aquatic), plants, microorganism, alcohol, chemicals, soil and water as long as they are not hazardous and najs. But the presence of alcohol, specifically ethanol in cosmetics is very great concern among Muslim consumers. Furthermore, in the study of (Abdullah Swidi, 2010), he explained that the global Muslim consumers have to know about the ingredients of the cosmetics, personal care products and the Halal status of these products to avoid using products with alcohol, pork fat and non-halal animal ingredients in these products.

(Kamaljeet Kaur, 2014) explained that halal cosmetics are products that must not contain any human parts or ingredients, any animal forbidden to Muslims or are not slaughtered according to Shariah law, no genetically modified organism (GMO) which are decreed as najs, no alcohol drinks (khamr), no contamination from najs during preparation processing, manufacturing and storage, and safe for consumer. (Nor, Ahmad, 
Yunus, \& Rose, n.d.) stated that it is difficult to find ethical cosmetics products that are not just free of animal by products, harmful chemicals, or alcohol but are also halal.

(Azmi) stated that the usage of alcohol in food, drinks, perfume and medicine in the Special discussion of the Fatwa Committee of the National Council for Islamic Religious Affairs Malaysia on 2011, was decided as follows; alcohol which derived from brewing process is haram and considered as fifth but alcohol which is not derived from nonliquor production processes is not filth but haram to drink because it is poisonous and harmful. Besides that, according to (Elasrag, 2016), alcohol which used in various forms, both for the maintenance of machinery and in the products themselves, is one aspect in Halal standard guidelines that differs between countries.

(YarKhan, 2008) explain all the above products with names ending in alcohol are not orally consumable products. They don't have relation to khamr, the common intoxicating alcoholic drink, and hence they are halal for use in skincare products only. In general, (Mohezar, 2016) explaining that the differs from the conventional product lines, the halal cosmetics brands do not contain porcine by-products and their derivatives as well as alcohol. It should be manufactured, stored packaged and distributed according to Islamic teaching. The halal beauty products are also recognized as clean, safe and of high quality.

(Noor, 2017) Similarly, Fatwa Committee National Council for Islamic Religious Affairs Malaysia (Muzakarah Jawatankuasa Fatwa Majlis Kebangsaan Bagi Hal Ehwal Ugama Is/am Malaysia) has met on 11-12 April 1984 to discuss the status of alcohol according to the Islamic view and has decide that:

1. Every alcoholic beverage contains alcohol. Not all alcohol has khamr. Alcohol from the process of making wine is haram and najs, but alcohol made not through the process of making wine is not najs but is prohibited to drink.

2. A soft drink made in the same manner as making alcohol either containing alcohol or distilled alcohol is prohibited to drink.

3. Soft drink is not made into khamr or intoxicating substances and are not the same as alcoholic beverages is halal.

4. Tapai is halal to eat.

5. Alcohol that is occurring as the byproduct from food processing is not najs and can be eaten.

6. Medicine and fragrance has alcohol are needed (harus) and forgiven. 
(Dr. Baker Alserhan, 2015) stated that the type of alcohol used in cosmetic products is ethyl alcohol. It is used in many cosmetic agents both for men (aftershave lotion) and women in perfumes. Ethyl alcohol is absorbed through the skin and flesh into the blood vessels and finally mixes with the blood and circulates throughout the body. Therefore, all products cosmetics containing ethyl alcohol are prohibited and haram. In addition, according to (Islam, 2013), cosmetics are considered halal when all ingredients comply with halal and Shariah requirements. Then, the haram ingredients such as alcohol and pigs are prohibited to be used in cosmetic products.

(Teng, 2013) stated that halal product must not contain ingredients that are not permissible or questionable such as alcohol, toxic chemicals, fats, placenta, gelatin from swine or animals that were not slaughtered according to the Islamic rules. Furthermore, most of the cosmetics and other personal care products are made by manufactures in non-Muslim countries and considered suspicious. Many international brands could be using enzymes extracted from pork or alcohol as a preservative. This is generating a lot of cynicism about these brand among Muslim consumers who are seeking for halal products (Briliana \& Mursito, 2017).

\section{Conclusion}

Most recently, women use branded cosmetics products available in the market that have the privilege of producing beauty, whitening, strengthening bones, reducing antiaging on the face and other. Majority of the products are not halal certified. This is a common problem among people who is concern about the halal status of beauty products available in their own country. As we know, alcohol is used widely in many ways which is difficult to avoid. Alcohol is widely used in skin care, perfume and other products that have their own purpose for the benefit of the skin. Furthermore, there are many different types of alcohol used in cosmetic products such as ethanol, cetyl alcohol, isopropyl alcohol and methanol. In addition, some cosmetics contained alcohol that can be absorbed through skin. In this issue, Muslim consumers need to be aware of the types of alcohol used in cosmetics. The selection need to be guided by the sources of Al-Quran and As-Sunnah. Meanwhile, the source and status of alcohol used in cosmetic products need to be verified as harmless and halal. Therefore, the Islamic community need to be careful in choosing cosmetics products that contain alcohol to be halal guaranteed for the well-being of the country. The halal status of alcohol in cosmetic products are depends on various factor, thus more studies and discussion in Shariah and scientific perspectives are needed to verify the halal status. 


\section{References}

[1] Gunia, K. J. (2018). Cinnamic Acid Derivatives in Cosmetics: Current Use and Future Prospects. Cosmetic science, pp. 1-11.

[2] Abdul, A. A. (2014). The Uncertain Halal Status of Edible Products with Natural or Added Alcohol. Journal of Fatwa Managment and Research, pp. 119-120.

[3] Swidi, C. W.-H. (2010). The Mainstream Cosmetics Industry In Malaysia And The Emergence, Growth, And Prospects Of Halal Cosmetics. Presented at The Third International Conference on International Studies (ICIS 2010), 1st-2nd December 2010, Hotel Istana Kuala Lumpur. College of Law, Government and International Studies, Universiti Utara Malaysia, p. 12.

[4] Abu-ras, W., Ahmed, S., and Arfken, C. (2010). Alcohol Use among Muslim Youth: Protective and Risk factors. Journal of Ethnicity in Substance Abuse Alcohol Use Among U.S. Muslim College Students: Risk and Protective Factors, https://doi.org/ 10.1080/15332640.2010.500921.

[5] Afifi, M., et al. (2014). Halal Pharmaceuticals: Legal, Shari'Ah Issues and Fatwa Of Drug, Gelatine and Alcohol. International Journal of Asian Social Science, vol. 4, issue 12, pp. 1176-1190.

[6] Ahmad, A. N., Rahman, A. A., and Rahman, S. A. (2015). Assessing Knowledge and Religiosity on Consumer Behavior towards Halal Food and Cosmetic Products. vol.5, issue 1, pp. 10-14, https://doi.org/10.7763/IJSSH.2015.V5.413.

[7] Alkohol, E., and Disinfekta, S. Perbedaan Efektifitas antara Alkohol 70 \% dengan Klorin 0.5 \% terhadap Jumlah Kuman pada Membran Stetoskop Penelitian eksperimental pada membran stetoskop di Ruang Baitul Izah, pp. 63-68.

[8] Azahari, F. (2010). Islamic Finance: Shariah Principles of "Transformation" and "Assimilation." Malayan Law Journal, vol. 1, pp. 24-51.

[9] Baranowska, I., et al. (2014). Determination of Preservatives in Cosmetics, Cleaning Agents and Pharmaceuticals Using Fast Liquid Chromatography. vol. 32, pp. 88-94.

[10] Bhatia, S. (2004). Esterification of Palmitic Acid with Methanol in the Presence of Macroporous Ion Exchange Resin as Catalyst, vol. 5, issue 2, pp. 35-51.

[11] Boonme, P. (2007). Applications of Microemulsions in Cosmetics, pp. 223-228.

[12] Briliana, V. and Mursito, N. (2017). Asia Pacific Management Review Exploring Antecedents and Consequences of Indonesian Muslim Youths' Attitude towards Halal Cosmetic Products: A case study in Jakarta. Asia Pacific Management Review, vol. 22, issue 4, pp. 176-184, https://doi.org/10.1016/j.apmrv.2017.07.012. 
[13] Cabaleiro, N., et al. (2012). Analytica Chimica Acta Enzymatic Single-Drop Microextraction for the Assay of Ethanol in Alcohol-Free Cosmetics Using Microvolume Fluorospectrometry Detection. Analytica Chimica Acta, vol. 733, pp. 28-33, https://doi.org/10.1016/j.aca.2012.04.039.

[14] Cirillo, N. A., et al. (2018). Enzymatic Kinetics of Cetyl Palmitate Synthesis in a SolventFree System. Biochemical Engineering Journal, vol. 137, pp. 116-124, https://doi.org/ 10.1016/j.bej.2018.05.021.

[15] The Star. (2012, March 28). Alcohol content: Many Still Confused as to What Is Haram. Retrieved from https://www.thestar.com.my/news/community/2012/03/28/ alcohol-content-many-still-confused-as-to-what-is-haram.

[16] Tarmizi, M. E. (2013). Haram Wealth: Contemporary Muamalah. in Haram Wealth: Contemporary Muamalah. Bogor: P.T Berkat Mulia Insani, pp. 53-54.

[17] Hashim, M. (2013). A Review of Cosmetic and Personal Care Products: Halal Perspective and Detection of Ingredient. Science \& Technology, vol. 21, pp. 281292.

[18] Hashim, P., et al. (2009). A Cosmetic Analysis in Compliance with the Legislative Requirements. Halal and Quality Control, vol. 11, issue 1.

[19] Hills, G. and Ag, D. (2003). Industrial Use of Lipases to Produce Fatty Acid, vol. 105, pp. 601-607. https://doi.org/10.1002/ejlt.200300853.

[20] Syed, N. N. (2018). Alcohol in Religious And Cultural Food. In M. E. NIzar, Preparation and Processing of Religious and Cultural Foods. United Kingdom: Elsevier, p. 280.

[21] Ishiwatari, M., et al. A. E. S. K. (1991). United States Patent (19), (19).

[22] Islam, T. (2013). International Journal of Management Research and Review, vol. 3, issue 12, pp. 3938-3948.

[23] Izhar, M., et al. (2017). Principles Regarding the Use of Haram (Forbidden) Sources in Food Processing: A Critical Islamic Analysis. vol.11, issue 22, pp. 17-25, https: //doi.org/10.5539/ass.v11n22p17.

[24] Jamaludin, M. A., et al. (2012). Fiqh Istihalah: Integration of Science and Islamic Law, vol. 2, issue 2, pp. 49-55.

[25] Jamaludin, M. A., Ramli, M. A. and Mat, D. (2014, May). Isu Penggunaan Alkohol Dalam Penghasilan Produk Gunaan Semasa: Analisis dari Perspektif Hukum Islam. Presented at Islamic Law in Contemporary Community Conference, pp. 1-12.

[26] Joseph, A. L. A. Y. D. A. N. G. H. (2013). Karakterisasi Produk Etanol dari Aren Characterising of the Ethanol Products from Palm Neera, pp. 1-5.

[27] Label, P. and Cashion, P. E. C. (1990). United States Patent (19), (19). 
[28] Liu, R., et al. (2014). Metabolic Engineering of Fatty Acyl-ACP Reductase-Dependent Pathway to Improve Fatty Alcohol Production in Escherichia coli. Metabolic Engineering, vol. 22, pp. 10-21, https://doi.org/10.1016/j.ymben.2013.12.004.

[29] Mahaiyadin, M. H. and Osman, M. R. (2017). Kesan Penerimaan Aplikasi Istihalah Terhadap Hukum Produk Yang Mengandungi Derivatif Muharramat. Jurnal Pengurusan Dan Penyelidikan Fatwa, vol. 10, issue 1, pp. 101-119.

[30] Majid, M. B., Sabir, I. and Ashraf, T. (2015). Consumer Purchase Intention towards Halal Cosmetics and Personal Care Products in Pakistan, vol. 1, issue 1, pp. 47-55.

[31] Michalak, L. and Katz, K. (2010). NIH Public Access, vol. 4, issue 1, pp. 1-15, https: //doi.org/10.1080/15564900902771325.

[32] Newman, J. L. (1999). United States Patent (19) 11 Patent Number, (19).

[33] Noor, L. M. (2018). Alkohol: Definisi, Pengharaman, Metabolisme Dan Kegunaannya [Alcohol: Definition, Prohibition, Metabolism and Its Usage], (March).

[34] Nor, S., et al. Hirao School of Management Review.

[35] Noor, U. M. (2017). Irsyad Al-Fatwa Siri Ke-185: Menggunakan Alcohol Swab Dan Minyak Wangi Beralkohol. Retrieved from https://muftiwp.gov.my/ms/artikel/irsyadfatwa/irsyad-fatwa-umum/953-irsyad-al-fatwa-siri-ke-185-menggunakan-alcoholswab-dan-minyak-wangi-beralkohol.

[36] Okamoto, T., Tomomasa, S. and Nakajima, H. (2016). Preparation and Thermal Properties of Fatty Alcohol/Surfactant/Oil/Water Nanoemulsions and Their Cosmetic Applications. Journal of Oleo Science, vol. 65, issue 1, pp. 27-36, https://doi.org/10. 5650/jos.ess15183.

[37] On, F. R. (1989). Impurities Following the Manufacturing Described Above, Impurities That May Be. pp. 67-92.

[38] Panggabean, S. R. (2013). Khamar Dan Alkohol; Sebuah Rekonstruksi Pemahaman, November issue, pp. 1-7.

[39] Rahim, A. A. (2016). The Uncertain Halal Status of Edible Products with Natural or Added Alcohol. https://doi.org/10.12816/0008152.

[40] Ramli, H. (2018). Determination of Alcohol Content in Halal Beverages. Nutritional Science, p. 8.

[41] Rassool, G. H. (2014). Cultural Competence in Caring for Muslim Patients. In G. H. Rassool, Cultural Competence in Caring for Muslim Patients. London: Palgrave Macmillan.

[42] Saiyasombati, P. and Kasting, G. B. (2003). Disposition of Benzyl Alcohol after Topical Application to Human Skin. In Vitro, vol. 92, issue 10, pp. 2128-2139. 
[43] Sawari, S. S., et al. (2015). E-Halal as Method and Apparatus for Halal Product Detection in Malaysia, vol. 6, issue 5, pp. 638-642, https://doi.org/10.5901/mjss. 2015.v6n5s2p638.

[44] Syariena, A. and Puziah, H. (2014). Rapid Determination of Residual Ethanol in Perfumery Products Using Headspace Gas Chromatography-Mass Spectrometry, vol. 22, issue 3, pp. 432-437, https://doi.org/10.5829/idosi.mejsr.2014.22.03.21906.

[45] Teng, P. K. (2013). Investigating Students Awareness and Usage Intention Towards Halal Labelled Cosmetics and Personal Care Products in Malaysia. March issue, pp. 367-376.

[46] Vieira, R. P., et al. (2009). Physical and Physicochemical Stability Evaluation of Cosmetic Formulations Containing Soybean Extract Fermented by Bifidobacterium Animalis, p. 45. 